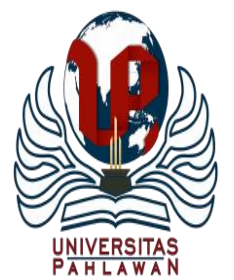

Jurnal Basicedu Volume 4 Nomor 4 Tahun 2020 Halaman 1291 - 1301

JURNAL BASICEDU

Research \& Learning in Elementary Education

https://jbasic.org/index.php/basicedu

\title{
Pengaruh Kemampuan Berpikir Kreatif untuk Meningkatkan Hasil Belajar Matematika di Sekolah Dasar
}

\author{
Alberth Supriyanto Manurung ${ }^{1}$, Abdul Halim ${ }^{2}$, Ainur Rosyid ${ }^{3}$ \\ Pendidikan Guru Sekolah Dasar, Universitas Esa Unggul, DKI Jakarta, Indonesia ${ }^{1,2,3}$. \\ E-mail: alberth@esaunggul.ac.id ${ }^{1}$ abdul.halim@esaunggul.ac.id ${ }^{2}$ ainur.rosyid@esaunggul.ac.id ${ }^{3}$
}

\begin{abstract}
Abstrak
Tujuan penelitian ini adalah untuk menentukan pengaruh kemampuan berpikir kreatif untuk meningkatkan hasil belajar matematika siswa kelas V SD. Metode penelitian yang digunakan adalah metode survei dan mengunakan teknik analisis regresi dan korelasi sederhana, regresi dan korelasi ganda. Penelitian ini dilakukan di SDN Kenari 07 Pagi Jakarta, Kecamatan Salemba, Jakarta Pusat dengan n = 36 dengan menggunakan teknik cluster sampling. Penelitian ini dilandasi dengan hipotesis-hipotesis sebagai berikut: (1) kemampuan berpikir kreatif memiliki pengaruh terhadap hasil belajar matematika; (2) minat memiliki pengaruh terhadap kemampuan berpikir kreatif; (3) latar belakang siswa memiliki pengaruh kemampuan berpikir kreatif; (4) intelegensia memiliki pengaruh kemampuan berpikir kreatif; (5) terdapat pengaruh antara bakat dan kemampuan berpikir kreatif dengan hasil belajar matematika. Berdasarkan penelitian ini diharapkan hasil belajar matematika siswa kelas V SD dapat ditingkatkan dengan pengaruh kemampuan berpikir kreatif, karena hasil verifikasi membuktikan bahwa kemampuan berpikir kreatif menjadi faktor-faktor penentu yang signifikan Kata kunci: kemampuan berpikir kreatif, hasil belajar matematika
\end{abstract}

Abstract

The purpose of this study was to determine the Effect of Creative Thinking Ability to improve Mathematics Learning Outcomes of Grade V SD Students. The research method used is a survey method and uses regression analysis techniques and simple correlation, multiple regression and correlation. This research was conducted at SDN Kenari 07 Pagi Jakarta, Salemba sub-district, Central Jakarta with $n=36$ using the cluster sampling technique. This research is based on the following hypotheses: (1) Creative Thinking Ability has an influence on mathematics learning outcomes; (2) Interests have an influence on Creative Thinking Ability; (3) The background of students has an influence on Creative Thinking Ability; (4) Intelligence has an influence on Creative Thinking Ability; (5) There is an influence between talent and Creative Thinking Ability with mathematics learning outcomes. Based on this research, it is hoped that the mathematics learning outcomes of grade V SD students can be improved by the influence of Creative Thinking Ability, because the verification results prove that the Creative Thinking Ability is a significant determining factor.

Keywords: creative thinking abilit, mathematics learning outcomes

Copyright (c) 2020 Alberth Supriyanto Manurung, Abdul Halim, Ainur Rosyid

$\triangle$ Corresponding author

Address : Petamburan VII no 18 Tanah Abang

Email : alberth@esaunggul.ac.id

ISSN 2580-3735 (Media Cetak)

Phone : 081375149899

ISSN 2580-1147 (Media Online)

DOI: https://doi.org/10.31004/basicedu.v4i4.544 
1292 Pengaruh Kemampuan Berpikir Kreatif untuk Meningkatkan Hasil Belajar Matematika di Sekolah Dasar - Alberth Supriyanto Manurung, Abdul Halim, Ainur Rosyid

DOI: https://doi.org/10.31004/basicedu.v4i4.544

\section{PENDAHULUAN}

Pembelajaran merupakan salah satu indikator penyelesaian masalah pendidikan dan merupakan jantung pendidikan, pembelajaran yang saat ini dikembangkan dan mulai menjadi acuan adalah konsep diri. Pembelajaran ini menjadikan peserta didik agar mampu mengembangkan kreativitas berpikir dan bertingkah laku yang baik sehingga benar-benar pembelajaran tersebut dapat menjadi inspirasi dan pada konteks ini pendidik berperan sebagai mentransferkan ilmu pengetahuan kepada peserta didik mulai dari mempermudah daya ingat sampai menemukan rumusan masalah. Teori pembelajaran ini mengambarkan sudut pandang peneliti mengenai aspek-aspek pembelajaran yang paling bernilai yang dipelajari, variabel-variabel independen yang harus dimanipulasi dan variabel-variabel dependen yang harus dikaji, teknik-teknik penelitian yang hendak digunakan untuk mendeskripsikan temuantemuan. Keterangan diatas memberikan pemahaman kepada pendidik untuk benar-benar memperhatikan model pembelajaran, karena sangat membantunya dalam memberikan pelajaran pada peserta didik untuk lebih kritis, objektif, analitis dan komperatif.

Dalam hal ini banyak model pembelajaran yang dipergunakan untuk menyelesaikan masalah pendidikan dan salah satunya adalah kemampuan berpikir kreatif yang pastinya mempengaruhi perkembangan dari anak yang mana setiap anak memiliki sifat yang berbeda-beda satu sama yang lain sehingga dapat menunjukkan karakter anak dalam menyelesaikan permasalahan yang dihadapi. Menurut beberapa ahli psikologi permasalahan diatas termasuk dalam perkembangan ilmu pengetahuan, hal ini dapat diamati melalui sikap yang mengambarkan aktualisasi anak tersebut. Manusia sebagai organisme yang memiliki dorongan untuk berkembang yang pada akhirnya menyebabkan ia sadar akan keberadaannya dan muncul sikap negatif terhadap kemampuan yang ia miliki sehingga memandang seluruh yang dikerjakan sebagai sesuatu yang sulit terselesaikan, sebaliknya untuk hal positif selalu memandang seluruh yang dikerjakan sebagai sesuatu yang amat mudah terselesaikan, secara umum kemampuan berpikir kreatif jelas dipengaruhi oleh lingkungannya sehingga perlu kajian yang lebih dalam bagaimana menyikapi permasalahan (Yudhawati. Ratna, 2011).

Tujuan segi teoritis penelitian ini dapat dipakai sebagai landasan penelitian lanjutan, khususnya variabel yang diteliti maupun pengungkapan variabel-variabel yang lebih kompleks yang berpengaruh dengan hasil belajar matematika siswa kelas V.

Dalam keseluruhan proses pendidikan di sekolah, kegiatan belajar merupakan kegiatan yang paling pokok, ini berarti bahwa berhasil tidaknya pencapaian tujuan pendidikan banyak bergantung kepada bagaimana proses belajar yang dialami oleh siswa sebagai anak didik (Slameto, 2010). Pandangan seseorang tentang belajar akan mempengaruhi tindakan-tindakannya yang berhubungan dengan belajar, dan setiap orang mempunyai pandangan yang berbeda tentang belajar dan untuk memperoleh pengertian yang objektif tentang belajar terutama belajar di sekolah perlu dikaji lebih mendalam tentang pengertian 
1293 Pengaruh Kemampuan Berpikir Kreatif untuk Meningkatkan Hasil Belajar Matematika di Sekolah Dasar - Alberth Supriyanto Manurung, Abdul Halim, Ainur Rosyid

DOI: https://doi.org/10.31004/basicedu.v4i4.544

belajar. Belajar menurut Hilgard dalam Ratna Yudhawati adalah proses dimana suatu perilaku muncul atau berubah karena adanya respon terhadap sesuatu situasi belajar agar mendapatkan suatu kepandaian, dalam implementasinya belajar adalah kegiatan individu memperoleh pendekatan perilaku dan keterampilan dengan cara mengolah bahan belajar. Menurut pengertian secara psikologis belajar merupakan suatu proses perubahan yaitu perubahan tingkah laku sebagai hasil dari interaksi dengan lingkungannya dalam memenuhi hidupnya. Perubahan-perubahan tersebut akan nyata dalam seluruh aspek tingkah laku.

Perubahan yang terjadi dalam diri seseorang banyak sekali baik sifat dan jenisnya karena itu sudah tentu tidak setiap perubahan dalam diri seseorang merupakan perubahan dalam arti belajar (Dale, 2012). Ada pengertian bahwa belajar adalah penambahan pengetahuan dan yang lain mengatakan bahwa belajar adalah berubah, dalam hal ini belajar merupakan usaha mengubah tingkah laku. Jadi belajar akan membawa dampak perubahan pada individu yang mau belajar (Desmita, 2010). Perubahan tidak sekedar penambahan ilmu pengetahuan tetapi membentuk kecakapan, keterampilan, sikap, pengertian, harga diri, minat, watak dan penyesuaian diri. Jelasnya mengandung semua aspek organisasi dan tingkah laku pribadi seseorang dengan demikian dapat dikatakan bahwa belajar itu sebagai rangkaian kegiatan jiwa raga, psiko-fisik untuk menuju perkembangan pribadi manusia seutuhnya, yang berarti menyangkut unsur cipta, rasa, karsa, ranah kognitif, afektif, dan psikomotorik.
Belajar matematika dapat melatih pola pikir, dengan terlatihnya pola pikir maka siswa memiliki kemampuan untuk menyelesaikan suatu masalah. Belajar matematika merupakan suatu aktifitas mental untuk memahami arti dari hubunganhubungan dan simbol-simbol yang terkandung dalam matematika secara sistematik, cermat dan tepat, kemudian menerapkan konsep-konsep yang dihasilkan untuk memecahkan masalah dalam berbagai hal/ keadaan/situasi nyata.

Ada beberapa teori yang berpendapat bahwa proses belajar pada prinsipnya bertumpu pada struktur kognitif, yakni penambahan fakta, konsep serta prinsip-prinsip, sehingga membentuk satu kesatuan yang memiliki makna bagi subjek didik. Untuk memperoleh suasana yang kondusif perlu adanya lingkungan yang mendukung sehingga dengan lingkungan belajar yang baik dapat mempengaruhi hasil belajar yang baik pula. Siswa adalah penentu terjadi atau tidak terjadinya proses belajar. Proses belajar terjadi berkat siswa memperoleh sesuatu yang ada disekitar lingkungan. Lingkungan yang ada berupa keadaan alam, benda-benda, hewan, tumbuhan-tumbuhan, manusia atau hal yang dijadikan bahan belajar. Tindakan belajar tentang suatu hal tersebut tampak sebagai perilaku belajar yang tampak dari luar. Salah satu upaya untuk meningkatkan kemampuan pemahaman dan pemecahan masalah siswa dengan memilih suatu pendekatan yang tepat untuk dapat lebih menekankan keaktifan siswa pada proses belajar mengajar berlangsung (Randy, 2008).

Pada saat orang belajar responnya menjadi lebih baik dan sebaliknya bila ia tidak belajar maka responnya menurun. Dalam ruang lingkup 
1294 Pengaruh Kemampuan Berpikir Kreatif untuk Meningkatkan Hasil Belajar Matematika di Sekolah Dasar - Alberth Supriyanto Manurung, Abdul Halim, Ainur Rosyid

DOI: https://doi.org/10.31004/basicedu.v4i4.544

sekolah belajar adalah suatu perubahan dalam kemungkinan atau peluang terjadinya respons dan dalam belajar ditemukan hal-hal sebagai berikut: (1) kesempatan terjadinya peristiwa yang menimbulkan respon belajar, (2) respon si pelajar, (3) konsekuensi yang bersifat menggunakan respons tersebut, baik konsekuensi hadiah maupun teguran. Belajar juga dapat diartikan sebagai suatu perubahan dalam kemungkinan atau peluang terjadinya respons. Peluang atau kemungkinan respons itu sukar mengukurnya, karena itu Skinner menyarankan agar belajar diukur menurut angka atau frekuensi respons. Meskipun tidak persis sama dengan peluang terjadinya perbuatan diwaktu yang akan datang, hal itu merupakan langkah awal dalam menganalisis perubahan tingkah laku, sehingga kejadian respons tersebut dapat dijadikan bahan pertimbangan untuk mengamati proses pembelajaran sesungguhnya.

Belajar dikatakan berhasil manakala seseorang mampu mengulangi kembali materi yang telah dipelajarinya, maka belajar disebut "rote learning", kemudian jika telah dipelajari itu mampu disampaikan dan diekspresikan dalam bahasa sendiri, maka disebut "over learning". Gagasan yang menyatakan bahwa belajar menyangkut perubahan dalam suatu organisme, berarti belajar juga membutuhkan waktu dan tempat. Belajar disimpulkan terjadi bila tampak tanda-tanda bahwa perilaku manusia sebagai akibat terjadinya proses pembelajaran. Perhatian utama dalam belajar adalah perilaku verbal dari manusia, yaitu kemampuan manusia untuk menangkap informasi mengenai ilmu pengetahuan yang diterimanya dalam belajar. Pada kesempatan yang berbeda menurut Dale Belajar merupakan proses yang berlangsung dalam jangka waktu yang lama melalui latihan dan pengalaman yang membawa perubahan diri dan perubahan cara mereaksi terhadap suatu perangsang tertentu. Pembelajaran yang bermakna akan terasa jika memiliki kaitan dengan keutuhan seseorang dan memiliki keterlibatan personal (perasaan pembelajar) yang diawali dari diri sendiri (dorongan belajar berasal dari dalam diri), meresap (mempengaruhi sikap, perilaku, dan kepribadian pembelajar) dan dievaluasi.

Sampai saat ini belum ada kesepakatan yang bulat diantara para ahli matematika, apa yang disebut dengan matematika itu. Sasaran penelaahan matematika tidaklah kongkret tetapi abstrak. Dengan mengetahui sasaran penelaahan matematika, kita dapat mengetahui hakikat matematika sesungguhnya sekaligus dapat mengetahui cara berpikir matematika tersebut. Kalau kita telaah, matematika itu tidak hanya berhubungan dengan bilangan-bilangan serta operasi-operasinya, melainkan juga unsur ruang sebagai sasarannya. Hubungan yang ada pada dalam matematika memang bertalian erat dengan kehidupan sehari-hari, misalnya tentang kesamaan pada lebih besar dan lebih kecil, hubungan tersebut kemudian diolah secara logika deduktif. Karena itu matematika dapat dikatakan sama dengan teori logika deduktif yang berkenaan dengan hubunganhubungan yang bebas dari isi materialnya hal-hal yang ditelaah.

Dari uraian diatas, sasaran matematika lebih dititikberatkan ke struktur sebab sasaran terhadap bilangan dan ruang tidak banyak artinya lagi dalam 
1295 Pengaruh Kemampuan Berpikir Kreatif untuk Meningkatkan Hasil Belajar Matematika di Sekolah Dasar - Alberth Supriyanto Manurung, Abdul Halim, Ainur Rosyid

DOI: https://doi.org/10.31004/basicedu.v4i4.544

matematika. Kenyataan yang lebih utama ialah hubungan-hubungan antara sasaran tersebut menetapkan langkah-langkah operasinya, hal ini mengandung bahwa matematika sebagai ilmu mengenai struktur yang mencakup hubunganhubungan dan simbol-simbolnya, simbol ini penting untuk membantu manipulasi aturan-aturan dengan operasi yang ditetapkan, simbolis menjamin adanya komunikasi dan mampu memberikan keterangan untuk membentuk konsep baru. Konsep baru ini terbentuk karena adanya pemahaman konsep sebelumnya sehingga matematika itu tersusun secara hirarkis. Simbol itu berarti bila suatu simbol dilandasi suatu ide. Jadi kita harus memahami ide yang terkandung dalam simbol tersebut, dengan perkataan lain ide harus dipahami terlebih dahulu sebelum ide tersebut disimbolkan. Secara singkat dikatakan matematika berkenaan ide-ide/konsep-konsep abstrak yang tersusun secara hirarkis dan penalarannya deduktif. Hal demikian membawa akibat kepada bagaimana terjadinya proses matematika (Ediyanto et al., 2020).

Belajar selalu berkenaan dengan perubahan tingkah laku, sedang perubahan tingkah laku dipelajari melalui psikologi, maka belajar itu sendiri tidak lepas dari sudut pandang psikologi. Para siswa diajak untuk mengkaji ulang segala pengetahuan yang didapat di kelas sehingga proses belajar dapat tercapai (Manurung. S. Alberth, 2015). Hasil belajar matematika pada dasarnya adalah hasil yang dicapai dalam usaha penguasaan materi dan ilmu pengetahuan yang merupakan suatu kegiatan yang menuju terbentuknya kepribadian seutuhnya. Melalui belajar dapat diperoleh hasil yang lebih baik. Pola tingkah laku manusia tersebut tersusun menjadi suatu model sebagai prinsip-prinsip belajar diaplikasikan ke dalam matematika. Prinsip belajar ini haruslah dipilih sehingga cocok untuk mempelajari matematika. Untuk meningkatkan hasil belajar matematika dan minat dalam belajar matematika, maka diperlukan adanya perubahan paradigma pembelajaran. Sehubungan dengan hal tersebut, berbagai model, strategi, metode maupun teknik pembelajaran telah silih berganti diterapkan dalam upaya meningkatkan kualitas hasil belajar matematika siswa. Matematika yang berkenaan dengan ide-ide abstrak yang diberi simbol dan tersusun secara hirarkis dan penalarannya deduktif, jelas belajar matematika itu memerlukan kegiatan mental yang tinggi. Untuk meningkatkan hasil belajar matematika dan minat dalam belajar matematika, maka diperlukan adanya perubahan paradigma pembelajaran (Jess, F., Gregory, 2006). Sehubungan dengan hal tersebut, berbagai model, strategi, metode maupun teknik pembelajaran telah silih berganti diterapkan dalam upaya meningkatkan kualitas hasil belajar matematika siswa.

Dari beberapa pendapat para ahli di atas maka dapat disimpulkan bahwa hasil belajar matematika dapat didefenisikan kemampuan atau pengetahuan siswa yang diperoleh melalui proses pembelajaran matematika selama kurun waktu tertentu sehingga menimbulkan daya pikir, daya nalar, berpikir logika, dan sistematis. Kemudian diaplikasikan dalam kehidupan sehari-hari.

Kemampuan berpikir kreatif merupakan salah satu fokus pembelajaran matematika. 
Pembelajaran matematika perlu dirancang sedemikian sehingga berpotensi mengembangkan kemampuan berpikir kreatif siswa. Pengembangan kemampuan berpikir kreatif perlu dilakukan seiring dengan pengembangan cara mengevaluasi atau cara mengukurnya. Isaken dalam Ali Mahmudi mendefinisikan berpikir kreatif sebagai proses konstruksi ide yang menekankan pada aspek kelancaran, keluwesan, kebaruan, dan keterincian sedangkan menurut Martin kemampuan berpikir kreatif adalah kemampuan untuk menghasilkan ide atau cara baru dalam menghasilkan suatu produk. Jika dihubunggkan dengan pelajaran matematika, ternyata kemampuan berpikir kreatif sangatlah diperlukan. Tujuannya tidak lain untuk mendorong para siswa dapat mengembangkan hasil pemikiran mereka tanpa harus terpaku pada cara yang telah diajarkan oleh guru. Agar kreativitas anak dapat terwujud dibutuhkan adanya dorongan dalam diri individu (motivasi intrinsik) maupun dorongan dari lingkungan (motivasi ekstrinsik).

Ciri berpikir kreatif ialah: a) mampu menghasilkan ide banyak dalam waktu singkat, b) mampu menghubungkan, menggabungkan hal yang berbeda, c) mampu mengembangkan hal yang sederhana, d) mampu bekerja secara detail dan kompleks, e) memilki rasa ingin tahu yang besar, f) berani mengambil resiko, g) cepat tanggap dan mandiri, h) suka mencari ide-ide yang unik.

Menurut Sumarmo, mengemukakan bahwa ada lima inti berpikir kreatif antara lain: (1) selfefficacy yaitu kemampuan dan kemandirian dalam mengontrol diri; berani menghadapi masalah; optimis, percaya diri, masalah sebagai tantangan dan peluang. (2) Luwes (flexibility) yaitu berempati, menghargai, menerima pendapat yang berbeda, bersikap terbuka, mantap/ toleran menghadapi ketidakpastian, memiliki rasa humor. (3) Kemahiran/kepakaran yaitu bekerja secara eksak, teliti, tepat, dan tuntas, punya visi dan tujuan yang jelas, selalu melakukan pengujian terhadap kegiatan yang dilakukan. (4) Kesadaran yaitu melakukan kegiatan secara sadar, berfikir metakognisi, memberikan alasan rasional terhadap kegiatan yang dilakukannya. (5) Rasa ketergantungan yaitu saling memberi dan menerima, menunjukkan keterkaitan, konflik sebagai sesuatu yang berguna.

Dari uraian di atas, dapat disimpulkan bahwa terdapat lima karakteristik berpikir kreatif yakni kelancaran, fleksibilitas, keaslian, elaborasi dan evaluasi akan memberikan suatu pandangan tentang proses kreatif, yang akan membantu individu untuk menciptakan ide-ide kreatif dalam menyelesaikan masalah tertentu (Wanelly \& Fauzan, 2020).

Beberapa karakteristik tersebut dapat digunakan sebagai indikator untuk mengukur kemampuan berpikir kreatif seseorang dalam menyelesaikan masalah tertentu, misalnya dalam bidang matematika. Kemampuan-kemampuan ini merepresentasikan proses menjadi sensitif pada pemahaman-pemahaman seseorang, dan merupakan ciri-ciri utama berpikir kreatif yang telah berkembang (Lawrence, A. P, Daniel, C, and Oliver, 2005). 
1297 Pengaruh Kemampuan Berpikir Kreatif untuk Meningkatkan Hasil Belajar Matematika di Sekolah Dasar - Alberth Supriyanto Manurung, Abdul Halim, Ainur Rosyid

DOI: https://doi.org/10.31004/basicedu.v4i4.544

\section{METODE}

Penelitian ini mengunakan metode survei dengan teknik korelasi yakni untuk mengetahui pengaruh kemampuan berpikir kreatif terhadap dengan hasil belajar matematika. Rancangan penelitian dalam penelitian ini adalah metode eksperimen. Untuk mengungkapkan hubungan antara dua variabel atau lebih atau mencari pengaruh suatu variabel terhadap variabel lainnya.

Sedangkan dalam penelitian ini sebelumnya dikondisikan homogen, selanjutnya salah satu kelompok sampel diberi perlakuan dengan konsep diri. Sedangkan kelompok yang lain diberi perlakuan pembelajaran metode ceramah. Subjek penelitian tindakan ini adalah siswa kelas V SDN Kenari 07 Pagi Jakarta. Metode pengumpulan data yang digunakan dalam penelitian ini adalah: metode kusioner dan metode tes. Metode pengumpulan data yang digunakan berupa kuesioner dan dokumenter.

Populasi penelitian ini adalah siswa kelas V SDN di Kecamatan Senen, Jakarta Timur, dalam hal ini mengambil populasi dari tiga SDN di Kecamatan Senen yang memiliki karakteristik dan kebiasaan siswa yang sama. Secara teori populasi dapat diartikan semua nilai baik hasil perhitungan maupun pengukuran, baik kuantitatif maupun kualitatif, dari karekteristik tertentu mengenai sekelompok objek yang lengkap dan jelas.

Sampel dalam penelitian ini adalah siswa kelas V SDN Kenari 07 Pagi yang diambil dengan mengunakan teknik cluster sampling. Dalam cluster sampling proses pengambilan sampel dengan cara memilih satu SDN dari tiga SDN yang mewakili satu kecamatan yang mempunyai karakteristik yang sama diantara SDN untuk dipilih menjadi sampel.

Teknik pengumpulan data merupakan suatu prosedur yang sistematis dan standar untuk memperoleh data yang diperlukan. Dalam suatu penelitian perlu memilih teknik pengumpulan data yang relevan untuk menjawab pokok permasalahan penelitian dan mencapai tujuan penelitian. Adapun beberapa tahapan yang ditempuh dalam proses pengumpulan data dalam penelitian adalah penentuan alat pengumpul data, alat yang digunakan untuk memperoleh data dalam penelitian hendaknya relevan dengan pertimbangan segi kepraktisan, efesiensi dan keandalan alat tersebut (Manurung. S. Alberth, 2015).

Instrumen penelitian ini adalah untuk memaparkan instrumen yang digunakan sesuai dengan variabel yang telah ditetapkannya. Instrumen variabel yang ditetapkan perlu adanya uji coba instrumen. Uji coba instrumen ini dimaksudkan adalah untuk mengetahui validitas reliabilitas soal serta butir-butir yang digunakan.

Data yang telah diperoleh dianalisis dengan bantuan komputer program Ms. Excel, untuk mendapatkan mean, median, modus, standar deviasi, range, distribusi frekuensi serta penyajian grafik histogram dari data setiap variabel terikat maupun bebas dalam penelitian.

Melakukan pengujian normalitas data, uji normalitas data dilakukan terhadap galat taksiran regresi $\hat{Y}$ atas $X_{1}$ dan $X_{2}$ dengan menggunakan statistik inferensial yaitu Lillefors. Dengan ketentuan apabila hasil analisis $\mathrm{L}_{\text {hitung }}<\mathrm{L}_{\text {tabel }}$ maka 
Ho diterima yang berarti sampel berdistribusi normal.

Menghitung koefisien korelasi sederhana antar variabel menggunakan rumusan pearson product moment dengan ketentuan bila $\mathrm{r}_{\text {hitung }}<\mathrm{r}_{\text {tabel }}$ maka Ho diterima yang berarti koefisien korelasi signifikan, serta koefisien parsial dengan uji-t, dengan ketentuan $\mathrm{t}_{\text {hitung }}>\mathrm{t}_{\text {tabel}}$, maka koefisisen korelasi signifikan (Sugiyono, 2010).

\section{HASIL DAN PEMBAHASAN}

Deskripsi data yang akan disajikan dari hasil penelitian ini adalah untuk memberikan gambaran secara umum mengenai penyebaran data yang diperoleh di lapangan. Data yang disajikan berupa data mentah yang diolah dengan menggunakan teknik deskripsi. Adapun dalam deskripsi data ini yang disajikan dengan bentuk distribusi frekuensi, total skor, harga skor rata-rata, simpangan baku, modus, median, skor maksimum dan skor minimum yang disertai histogram.

Deskripsi data berguna untuk menjelaskan penyebaran data menurut frekuensinya, untuk menjelaskan kecendrungan terbanyak, kecendrungan tengah, dan untuk menjelaskan pola penyebaran (maksimum-minimum), untuk menjelaskan pola penyebaran data atau homogenitas data.

Berdasarkan judul dan permasalahan masalah penelitian dimana penelitian ini terdiri dari dua variabel bebas dan satu variabel terikat yakni meliputi data Hasil Belajar Matematika (Y), Kemampuan Berpikir Kreatif (X). Data yang di kumpulkan dari 36 Siswa kelas V SDN Kenari 07 di Kecamatan Matraman, Jakarta Timur dengan mengunakan dua instrumen tes yaitu instrumen hasil belajar matematika, instrumen kemampuan berpikir kreatif.

Data hasil belajar matematika diperoleh melalui tes dengan 25 butir pertanyaan dengan 36 responden. Setiap butir pertanyaan yang dijawab dengan benar diberi skor 1 dan yang salah diberi skor 0 , sehingga rentang skor teoretik adalah antara 0 sampai dengan 25. Berdasarkan data observasi yang terkumpul diperoleh skor maksimum 21 dan skor minimum 2, rentang empirik antara 2 - 21, rata-rata 10,1667, Simpangan baku (SD) 4,65, Modus (Mo) 6,47, Median (me) 9,5 dan Varian 21,65. Distribusi variabel Hasil Belajar Matematika disajikan pada tabel 1 sebagai berikut:

Tabel 1. Distribusi Hasil Belajar Matematika

\begin{tabular}{|c|c|c|c|c|c|}
\hline $\begin{array}{c}\text { Nilai } \\
\text { Matematika }\end{array}$ & $\mathrm{f}_{\mathrm{i}}$ & $\begin{array}{c}\text { Nilai } \\
\text { tengah }\end{array}$ & $\mathrm{f}_{\mathrm{k}}$ & $\mathrm{f}_{\mathrm{r}} \%$ & $\mathrm{f}_{\mathrm{i}} \mathrm{X}$ \\
\hline $2 .-4$ & 2 & 3 & 2 & 5,555556 & 6 \\
\hline $5 .-7$ & 12 & 6 & 14 & 33,33333 & 72 \\
\hline $8 .-10$ & 6 & 9 & 20 & 16,66667 & 54 \\
\hline $11 .-13$ & 8 & 12 & 28 & 22,22222 & 96 \\
\hline $14 .-16$ & 4 & 15 & 32 & 11,11111 & 60 \\
\hline $17 .-19$ & 2 & 18 & 34 & 5,555556 & 36 \\
\hline $20 .-22$ & 2 & 21 & 36 & 5,555556 & 42 \\
\hline
\end{tabular}

Data kemampuan berpikir kreatif diperoleh melalui kuesioner dengan 22 butir pernyataan dengan 36 responden. Pemberian skor dilakukan dengan skala Likert, menggunakan lima alternatif jawaban, yaitu: Sangat sering, Sering, Kadangkadang, Jarang dan Tidak pernah. Rentang skor teoretik adalah antara 22 sampai dengan 220. Berdasarkan data observasi yang terkumpul diperoleh skor maksimum 96 dan skor minimum 63, rentang empirik antara 63-96, rata-rata 81,667, 
Simpangan baku (SD) 8,22, Modus (Mo) 77,93, Median (me) 80,07 dan Varian 67,60. Distribusi variabel Kemampuan Berpikir Kreatif disajikan pada tabel 2 sebagai berikut:

Tabel 2. Distribusi Kemampuan Berpikir Kreatif

\begin{tabular}{|c|c|c|c|c|c|}
\hline $\begin{array}{l}\text { Kemampuan } \\
\text { Berpikir } \\
\text { kreatif }\end{array}$ & $\mathrm{f}_{\mathrm{i}}$ & $\begin{array}{l}\text { Nilai } \\
\text { tengah }\end{array}$ & $\mathrm{f}_{\mathrm{k}}$ & $\mathrm{f}_{\mathrm{r}} \%$ & $\mathrm{f}_{\mathrm{i}} \mathrm{X}$ \\
\hline $63-68$ & 3 & 65,5 & 3 & 8,333 & 196,5 \\
\hline $69-74$ & 2 & 71,5 & 5 & 5,556 & 143 \\
\hline $75-80$ & 14 & 77,5 & 19 & 38,889 & 1085 \\
\hline $81-86$ & 5 & 83,5 & 24 & 13,889 & 417,5 \\
\hline $87-92$ & 8 & 89,5 & 32 & 22,222 & 716 \\
\hline $93-98$ & 4 & 95,5 & 36 & 11,111 & 382 \\
\hline
\end{tabular}

Untuk persamaan regresi umum $\hat{\mathrm{Y}}=\mathrm{a}+\mathrm{bX}$ diperoleh $\mathrm{a}=-8,74$ dan slope $\mathrm{b}=0,23$ oleh karena itu persamaan regresi umum $\hat{Y}=-8,74+0,23 X$. Pengujian galat taksiran regresi $\hat{Y}$ atas $X$ menghasilkan $\mathrm{L}_{\text {hitung }}$ maksimum sebesar 0,078 . Adapun $\mathrm{L}_{\text {tabel }}$ pada taraf nyata $\alpha=0,05$ diperoleh nilai sebesar 0,147. Dari hasil perbandingan antara $\mathrm{L}_{\text {hitung }}$ dan $\mathrm{L}_{\text {tabel }}$ ternyata $\mathrm{L}_{\text {hitung }}<\mathrm{L}_{\text {tabel }}$ yaitu $\quad 0,078$ $<0,147$, dari hasil tersebut $\mathrm{H}_{\mathrm{o}}$ diterima dan dapat disimpulkan bahwa galat taksiran regresi $\hat{Y}$ atas $\mathrm{X}$ berdistribusi normal.

Setelah persyaratan analisis data terpenuhi, dilakukan analisis inferensial untuk menguji hipotesis yang dilakukan untuk menarik kesimpulan apakah hipotesis penelitian yang telah dirumuskan didukung oleh data empirik yang diperoleh.

Pengujian hipotesis penelitian ini mengunakan rumusan regresi dan korelasi. Hipotesis dianalisis dengan rumusan regresi dan korelasi sederhana, rincian hasil pengujian sebagai berikut: pengujian analisis regresi serhana meliputi uji signifikansi regresi dan uji linieritas regresi yang dilakukan dengan uji F. Sedangkan pengujian analisis korelasi sederhana adalah berupa uji signifikansi korelasi menggunakan uji t. Teknik korelasi sederhana yang digunakan adalah Product Person Moment.

Hipotesis yang diuji adalah

$$
\begin{aligned}
& \mathrm{H}_{0}: \rho_{\mathrm{y} 1} \leq 0 \\
& \mathrm{H}_{1}: \rho_{\mathrm{y} 1}>0
\end{aligned}
$$

Rumusan hipotesis penelitian adalah terdapat kontribusi positif antara kemampuan berpikir kreatif $(\mathrm{X})$ dan hasil belajar matematika (Y). Dari hasil analisis regresi diperoleh bahwa kontribusi antara kemampuan berpikir kreatif (X) dan hasil belajar matematika (Y) digambarkan dengan persamaan $\hat{Y}=-8,739+0,231 X$. Untuk mengetahui model persamaan regresi diatas signifikan atau tidak dilakukan uji signifikansi dan linieritas regresi dengan analisis varians. Rangkuman hasil perhitungan uji signifikansi dan linieritas regresi antara Kemampuan Berpikir Kreatif (X) dan hasil belajar matematika (Y). Regresi signifikan $\left(\mathrm{F}_{\text {hitung }}=6,82>\mathrm{F}_{\text {tabel }}=4,13\right.$ ) Regresi linier $\left(\mathrm{F}_{\text {hitung }}=1,33<\mathrm{F}_{\text {tabel }}=2,23\right)$.

Selanjutnya dilakukan pengujian korelasi dengan Product Person Momen untuk mengetahui kekuatan Pengaruh antara variabel kemampuan berpikir kreatif dan variabel hasil belajar matematika. Dari hasil perhitungan didapat koefisien korelasi sebesar $r_{x y}=0,409 . \quad$ Uji keberartian koefisien korelasi dengan uji $t$ diperoleh harga $t_{\text {hitung }}$ sebesar 2,61 sedangkan $t_{\text {tabel }}$ pada taraf signifikan $\alpha=0,05$ dengan derajat kebebasan 34 diperoleh harga $t_{\text {tabel }}=1,69$ Kekuatan kontribusi variabel $\mathrm{X}$ dengan $\mathrm{Y}$ 
1300 Pengaruh Kemampuan Berpikir Kreatif untuk Meningkatkan Hasil Belajar Matematika di Sekolah Dasar - Alberth Supriyanto Manurung, Abdul Halim, Ainur Rosyid

DOI: https://doi.org/10.31004/basicedu.v4i4.544

ditunjukkan dengan koefisien korelasi. terlihat hasil analisis uji $t$ diperoleh $t_{\text {hitung }}$ sebesar 2,61 dan $\mathrm{t}_{\text {tabel }}$ sebesar 1,69 artinya terdapat kontribusi yang positif antara variabel Kemampuan Berpikir Kreatif dan hasil belajar matematika karena $t_{\text {hitung }}>$ $t_{\text {tabel }}$ yaitu 2,61 > 1,69. koefisien Determinasi sebesar 0,1672 , menerangkan bahwa $16,72 \%$ variansi variabel hasil belajar matematika dijelaskan atau ditentukan oleh kemampuan berpikir kreatif. Dari hasil perhitungan analisis diatas dapat disimpulkan bahwa terdapat hubungan yang positif antara variabel kemampuan berpikir kreatif dan variabel hasil belajar matematika.

\section{SIMPULAN}

Berdasarkan hasil perhitungan pengujian dan analisis yang telah dikemukakan diatas, terlihat bahwa terdapat kontribusi positif antara variabel bebas dengan variabel terikat. Hasil pengujian dan analisis menunjukkan bahwa kemampuan berpikir kreatif memberikan kontribusi dalam mementukan hasil belajar matematika. Berdasarkan hasil pengujian hipotesis terlihat bahwa variabel kemampuan berpikir kreatif dengan hasil belajar matematika memiliki persamaan regresi linier $\hat{Y}=-8,739+0,231 X$. Setelah dilakukan pengujian, model persamaan regresi tersebut adalah linier dan signifikan pada taraf $\alpha=0,05$. hal ini berarti setiap kenaikan satu skor dari kemampuan berpikir kreatif diikuti oleh kenaikan skor prestasi belajar matematika sebesar 0,231 pada konstanta $-8,739$.

Kontribusi antara variabel kemampuan berpikir kreatif dengan hasil belajar matematika memiliki koefisien korelasi sebesar $r_{x y}=0,409$ dan koefisien Determinasi sebesar 0,1672 , menerangkan bahwa $16,72 \%$ variansi variabel hasil belajar matematika dijelaskan atau ditentukan oleh kemampuan berpikir kreatif. Dengan demikian hipotesis penelitian yang menyatakan terdapat kontribusi positif antara variabel kemampuan berpikir kreatif dengan hasil belajar matematika secara statistik teruji kebenarannya.

\section{DAFTAR PUSTAKA}

Dale. (2012). Learning Theories an Education Perspective. Pustaka Pelajar.

Desmita. (2010). Psikologi perkembangan peserta didik. Rosda Karya.

Ediyanto, E., Gistituati, N., Fitria, Y., \& Zikri, A. (2020). Pengaruh Pendekatan Realistic Mathematics Education Terhadap Motivasi Dan Hasil Belajar Materi Matematika Di Sekolah Dasar. Jurnal Basicedu, 4(1), 203 209.

https://doi.org/10.31004/basicedu.v4i1.325

Jess, F., Gregory, J. F. (2006). Theories of Personality. McGraw Hill.

Lawrence, A. P, Daniel, C, and Oliver, P. J. (2005). Personality Theory and Research. John Wiley \& Sons.

Manurung. S. Alberth. (2015). Hubungan Antara Motivasi Berprestasi Terhadap Hasil. 1.

Randy, J. L. and D. M. B. (2008). Personality Psychology Domain of Knowledge About Nature. McGraw-Hill Companies.

Slameto. (2010). Belajar \& Faktor-Faktor yang mempengaruhi. Rineka Cipta.

Sugiyono. (2010). Statistika untuk penelitian. Alfabeta.

Wanelly, W., \& Fauzan, A. (2020). Pengaruh Pendekatan Open Ended dan Gaya Belajar Siswa terhadap Kemampuan Berpikir Kreatif 
1301 Pengaruh Kemampuan Berpikir Kreatif untuk Meningkatkan Hasil Belajar Matematika di Sekolah Dasar - Alberth Supriyanto Manurung, Abdul Halim, Ainur Rosyid DOI: https://doi.org/10.31004/basicedu.v4i4.544

Matematis. Jurnal Basicedu, 4(3), 523-533.

https://doi.org/10.31004/basicedu.v4i3.388

Yudhawati. Ratna, dan H. D. (2011). Teori-Teori

Dasar Psikologi Pendidikan. P.T Prestasi

Pustakaraya. 